\title{
PENGARUH KOMPENSASI DAN BEBAN KERJA TERHADAP KEPUASAN KERJA DALAM MENINGKATKAN KINERJA KARYAWAN PT. KEPSINDO INDRA UTAMA PADANG
}

\author{
Rika Wahyuni, Hadi Irfani \\ Universitas Putra Indonesia "YPTK" Padang \\ E-mail: rikawahyuni070685@gmail.com
}

\begin{abstract}
This study aims to analyze how compensation and workload effect on job satisfaction; compensation and workload effect on employee performance; and job satisfaction effect on employee's performance at the PT. Kepsindo Indra Utama Padang. Type of this research is quantitative research. The samples are 80 employees of the PT. Kepsindo Indra Utama Padang using saturation sampling technique. Methods of data collection is using questionnaire. This research is using path analysis. The results showed that: 1) compensation has positive and significant impact on job satisfaction, 2) workload have negative and significant impact on job satisfaction, 3) compensation has positive and significant impact on employee performance, 4) workload has negative and significant impact on employee performance, and 5) job satisfaction has positive and significant impact on employee performance. The results showed that the direct path of job compensation has the most powerful effect on employee performance demonstrated by having the highest impact regression coefficient (dominant) amounted to 0,664.
\end{abstract}

Kata Kunci: Compensation, Workload, Job Satisfaction and Employees Performance

\begin{abstract}
ABSTRAK
Penelitian ini bertujuan untuk menganalisis bagaimana kompensasi dan beban kerja berpengaruh pada kepuasan kerja; kompensasi dan beban kerja berpengaruh pada kinerja karyawan; dan pengaruh kepuasan kerja terhadap kinerja karyawan pada PT. Kepsindo Indra Utama Padang. Jenis penelitian ini adalah penelitian kuantitatif. Sampel penelitian adalah 80 karyawan PT. Kepsindo Indra Utama Padang menggunakan teknik sampling jenuh. Metode pengumpulan data menggunakan kuesioner. Penelitian ini menggunakan analisis jalur. Hasil penelitian menunjukkan bahwa: 1) kompensasi berpengaruh positif dan signifikan terhadap kepuasan kerja, 2) beban kerja berdampak negatif dan signifikan terhadap kepuasan kerja, 3) kompensasi berpengaruh positif dan signifikan terhadap kinerja karyawan, 4) beban kerja berdampak negatif dan signifikan terhadap kinerja karyawan, dan 5) kepuasan kerja berpengaruh positif dan signifikan terhadap kinerja karyawan. Hasil penelitian menunjukkan bahwa jalur langsung kompensasi pekerjaan memiliki pengaruh paling kuat terhadap kinerja karyawan yang ditunjukkan dengan memiliki koefisien regresi dampak paling tinggi (dominan) sebesar 0,664.
\end{abstract}

Kata Kunci: Kompensasi, Beban Kerja, Kepuasan Kerja dan Kinerja Karyawan

\section{PENDAHULUAN}

PT. Kepsindo Indra Utama Padang adalah perusahaan yang bergerak di bidang kontraktor, supplier, outsourcing tenaga kerja, perbengkelan dan dealer dari sepeda motor KTM. Pencapaian hasil kerja yang tidak maksimal menjadi masalah yang terus dilakukan perbaikannya oleh perusahaan. Masalah yang dihadapi yakni capaian laba perusahaan yang mengalami penurunan pada periode 2015-2017. Rasio laba bersih tahun 2015 sebesar $5,5 \%$ menurun $4,8 \%$ tahun 2016 , mengalami penurunan kembali pada tahun 
2017 sebesar 4,24\%. Kondisi ini memperlihatkan bahwa pengelolaan karyawan pada PT. Kepsindo Indra Utama Padang belum efektif.

Faktor penentu meningkatnya kinerja karyawan salah satunya adalah kepuasan kerja. Sebagaimana hasil penelitian Perera, et al (2014) menunjukkan adanya pengaruh positif kepuasan kerja terhadap kinerja karyawan. Untuk memperjelas dan mengetahui kepuasan kerja karyawan, penulis melakukan pra survey terhadap pelaksanaan operasional PT. Kepsindo Indra Utama Padang yang terlihat dari data turnover karyawan pada tahun 2015 tingkat turn over mencapai 10\%, meningkat ditahun 2016 sebesar 15\% dan tahun 2017 tingkat turn over kembali mengalami peningkatan sebesar 20\%. Hal ini menandakan bahwa kurang puasnya karyawan terhadap pekerjaan dapat menyebabkan peningkatan turnover pada perusahaan sehingga berdampak terhadap kerugian perusahaan.

Pemberian kompensasi bertujuan untuk meningkatkan kepuasan karyawan dalam melaksanakan pekerjaan serta mendorong peningkatkan kinerja karyawan. Pontoh (2014) menyatakan bahwa adanya pengaruh langsung positif dan signifikan dari kompensasi terhadap kepuasan kerja serta pengaruh langsung positif dan signifikan kompensasi terhadap kinerja karyawan. Hasil wawancara pada karyawan PT. Kepsindo Indra Utama Padang permasalahan kompensasi yang terjadi adalah adanya ketidakadilan yang dirasa karyawan dalam pembagian bonus, gaji yang tidak sesuai dengan jabatan, dan kompensasi yang diterima karyawan belum mencukupi kebutuhan hidup. Beban kerja merupakan unsur penting bagi karyawan sebagai penentu kepuasan karyawan dan berdampak terhadap kinerja karyawan. Penelitian Mustapha (2013) membuktikan bahwa beban kerja berpengaruh terhadap kepuasan kerja, artinya karyawan lebih puas terhadap pekerjaan ketika beban kerja yang mereka dapatkan lebih rendah. Hasil penelitian sebelumnya pernah menguji pengaruh beban kerja terhadap kinerja karyawan salah satunya adalah Tjiabrata, dkk (2017), yang menguji pengaruh beban kerja terhadap kinerja karyawan PT. Sabar Ganda Manado, hasil menemukan bahwa beban kerja berpengaruh positif terhadap kinerja karyawan. Adanya perbedaan hasil penelitian membuat pengaruh beban kerja terhadap kinerja karyawan menjadi suatu hal yang menarik untuk diteliti.

Hasil observasi pada PT. Kepsindo Indra Utama Padang diketahui bahwa beban kerja yang diterima oleh karyawan cukup tinggi sehingga seringkali karyawan harus melakukan lembur agar target pekerjaan dapat tercapai. Beban kerja yang meningkat, munculnya konflik antar departemen dan penetapan target pencapaian yang tinggi secara langsung maupun tidak langsung ditambah dengan kompensasi yang kurang mendukung dapat menyebabkan menurunnya tingkat kepuasan kerja karyawan sehingga berdampak terhadap penurunan kinerja karyawan.

\section{TINJAUAN LITERATUR}

Mathis dan Jackson (2011:378) menyatakan kinerja (performance) pada dasarnya adalah apa yang dilakukan atau tidak dilakukan oleh pegawai. Umumnya kinerja berkaitan dengan kuantitas kerja, kualitas hasil, ketepatan waktu dari hasil, kehadiran karyawan, dan kemampuan bekerja sama. Pendapat yang dikemukakan oleh Calvin (2017) menyatakan bahwa 
kinerja adalah harapan perusahaan terhadap keseluruhan nilai dari serangkaian perilaku yang berlainan yang dibawa individu hingga akhir standar periode waktu. Koopmans, dkk (2014:158-160) membagi kinerja karyawan kedalam tiga indikator; 1) kinerja tugas (task performance), 2) kinerja kontektual (contextual performance), dan 3) perilaku kerja produktif (productive work behavior).

Kepuasan kerja adalah evaluasi karyawan atas perasaan senang maupun tidak senang, puas maupun tidak puas dalam melaksanakan pekerjaan (Rivai, 2013:856). Pendapat Siagian (2013:295) mengenai kepuasan kerja merupakan cara pandang karyawan dalam penilaian positif ataupun negatif atas pekerjaan yang dilakukannya. Sedangkan pendapat Sunyoto (2013:210) mengenai kepuasan kerja adalah keadaan emosional karyawan baik menyenangkan maupun tidak menyenangkan dalam menilai pekerjaannya. Pada penelitian ini indikator kepuasan kerja yang digunakan mengacu pada teori Rivai (2013:860) yaitu; 1) isi pekerjaan, 2) penampilan tugas pekerjaan yang aktual dan sebagai kontrol terhadap pekerjaan, 3) supervisi, 4) organisasi dan manajemen, 5) kesempatan untuk maju, 6) gaji dan keuntungan dalam bidang finansial lainnya, 7) rekan kerja, dan 8) kondisi pekerjaan.

Kompensasi menjadi komponen penting yang berhubungan dengan karyawan. Rivai (2013:741) menjelaskan kompensasi adalah pengganti jasa yang diterima karyawan pada perusahaan. Pendapat Dessler dalam Subekhi (2012:175) mengenai kompensasi adalah berupa pembayaran maupun imbalan atas pekerjaan dari perusahaan atas pekerjaan yang dilakukan. Kompensasi kerja adalah sesuai yang diterima karyawan sebagai balasa jasa atas pekerjaan karyawan (Triyono, 2012). Indikator-indikator kompensasi mengacu pada teori Rivai (2013:744) adalah: 1) gaji, 2) insentif, dan 3) asuransi-asuransi.

Beban kerja merupakan pekerjaan yang dilakukan dengan uraian tugas yang seharusnya diselesaikan pada batas waktu tertentu (Tarwaka, 2011:106). Pendapat Meshkati dalam Zaki dan Marzolina (2016) mengenai beban kerja sebagai perbandingan kemampuan karyawan dengan tuntutan pekerjaan yang berarti jika karyawan memiliki kemampuan kerja lebih tinggi daripada tuntutan pekerjaan akan memunculkan rasa bosan, sebaliknya jika kemampuan karyawan lebih rendah daripada tuntutan pekerjaan maka akan muncul perasaan kelelahan yang lebih. Indikator yang dipergunakan untuk mengetahui beban kerja yang dikembangkan dari hasil penelitian Zaki dan Marzolina (2016) yang terdiri dari; 1) Banyaknya pekerjaan, 2) target kerja, 3) kebosanan, 4) kelebihan beban, dan 5) tekanan kerja.

Selanjutnya untuk lebih memudahkan penelitian dan pembahasan, maka peneliti mengemukakan bagan atau skema yang akan dijadikan sebagai pedoman dalam penelitian ini. Secara sistematis model penelitian dalam penulisan ini digambarkan dalam kerangka konseptual seperti gambar berikut : 


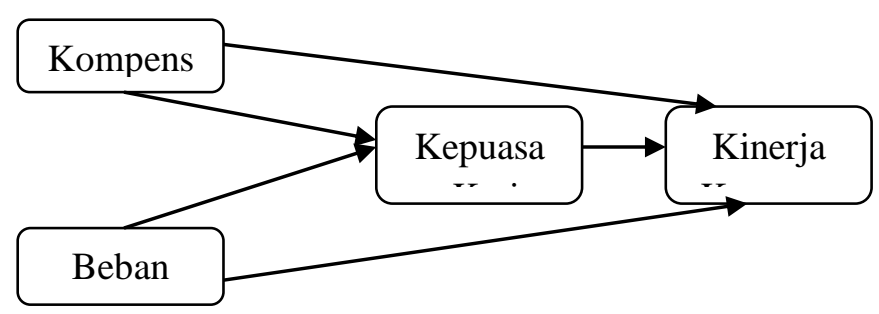

\section{METODOLOGI}

Penelitian ini dilakukan di PT. Kepsindo Indra Utama Padang yang beralamat di Jl. Blok B No.03 Kel. Batu Gadang Indarung Padang. Populasi penelitian adalah seluruh karyawan PT. Kepsindo Indra Utama Padang yang berjumlah 80 orang diambil sampel 80 orang dengan menggunakan teknik sampling jenuh. Sugiyono (2013:122) menyatakan sampling jenuh adalah teknik pengumpulan sampel bila semua anggota populasi digunakan sebagai sampel.

Variabel penelitian terdiri dari variabel eksogen yaitu kompensasi dan beban kerja sebagai variabel eksogen, variabel moderator yaitu kepuasan kerja dan variabel endogen yaitu kinerja karyawan. Pendekatan penelitian adalah kuantitatif dengan metode analisis jalur (path analysis) berbantukan program Amos.

\section{HASIL PENELITIAN DAN PEMBAHASAN}

Analisis jalur digunakan untuk mengetahui pengaruh dari variabel bebas terhadap variabel terikat.

Tabel 1. Hasil Kesimpulan Regresi Jalur Total

\begin{tabular}{|c|l|c|c|}
\hline \multirow{2}{*}{ No } & \multicolumn{2}{|c|}{ Model Pengaruh } & \multicolumn{2}{|c|}{ Regresi } \\
\cline { 3 - 4 } & & Beta & Sig \\
\hline 1 & Kompensasi $\rightarrow$ Kepuasan & 0,595 & 0,000 \\
\hline 2 & Beban kerja $\rightarrow$ Kepuasan & $-0,236$ & 0,006 \\
\hline 3 & Kompensasi $\rightarrow$ Kinerja & 0,664 & 0,000 \\
\hline 4 & Beban kerja $\rightarrow$ Kinerja & $-0,146$ & 0,034 \\
\hline 5 & Kepuasan $\rightarrow$ Kinerja & 0,190 & 0,026 \\
\hline
\end{tabular}

Sumber: Data Diolah, 2018

Tabel 2. Hasil Direct Effect, Indirect Effect dan Total Effect

\begin{tabular}{|c|l|c|c|c|c|}
\hline No & \multicolumn{1}{|c|}{ Model Pengaruh } & $\begin{array}{c}\text { Direct } \\
\text { Effect }\end{array}$ & $\begin{array}{c}\text { Indirect } \\
\text { Effect }\end{array}$ & $\begin{array}{c}\text { Total } \\
\text { Effect }\end{array}$ & Status \\
\hline 1 & Kompensasi $\rightarrow$ Kinerja & 0,664 & - & - & Signifikan \\
\hline 2 & Beban kerja $\rightarrow$ Kinerja & $-0,146$ & - & - & Signifikan \\
\hline 3 & Kepuasan $\rightarrow$ Kinerja & 0,190 & - & - & Signifikan \\
\hline 4 & Kompensasi $\rightarrow$ Kepuasan $\rightarrow$ Kinerja & - & 0,113 & 0,777 & Signifikan \\
\hline 5 & Beban kerja $\rightarrow$ Kepuasan $\rightarrow$ Kinerja & - & $-0,045$ & $-0,0191$ & Signifikan \\
\hline
\end{tabular}

Sumber: Data Diolah, 2018

\section{a. Pengaruh Kompensasi Terhadap Kepuasan Kerja PT. Kepsindo Indra Utama Padang}


Hasil uji hipotesis menunjukkan nilai koefisien regresi sebesar 0,595 dengan nilai signifikansi yaitu $0,000<0,05$. Hal ini berarti kompensai berpengaruh positif dan signifikan terhadap kepuasan kerja PT. Kepsindo Indra Utama Padang. Hasil penelitian ini mendukung pendapat Notoadmodjo dalam Kurniawan, dkk (2014) yang menyatakan bahwa pemberian kompensasi yang tepat dan benar akan membuat karyawan merasakan kepuasan dalam bekerja dan termotivasi untuk mencapai tujuantujuan organisasi, sebaliknya jika kompensasi yang diberikan kurang tepat dan tidak memadai maka akan menyebabkan prestasi, motivasi, dan kepuasan kerja pada karyawan mengalami penurunan.

Sejalan dengan pendapat di atas, hasil penelitian Adeoye dan Fields (2014), Gupta (2014), dan Muguongo (2015), menyatakan bahwa kompensasi berpengaruh signifikan terhadap kepuasan kerja. Artinya jika kompensasi yang diterima tidak cukup dan tidak memadai maka tingkat kepuasan kerja karyawan akan rendah demikian sebaliknya. Kompensasi menjadi faktor penentu kepuasan kerja karyawan dikarenakan alasan uang adalah instrument penting dalam memenuhi kebutuhan karyawan serta karyawan memandang gaji sebagai bentuk kepedulian manajemen terhadap mereka.

\section{b. Pengaruh Beban Kerja Terhadap Kepuasan Kerja PT. Kepsindo Indra Utama Padang}

Hasil uji hipotesis menunjukkan nilai koefisien regresi sebesar -0,236 dengan nilai signifikansi yaitu $0,006<0,05$. Hal ini berarti beban kerja berpengaruh negatif dan signifikan terhadap kepuasan kerja PT. Kepsindo Indra Utama Padang. Hal ini mengindikasikan bahwa beban kerja merupakan salah satu faktor yang mempengaruhi kepuasan kerja, semakin tinggi beban kerja semakin menurun tingkat kepuasan kerja yang ada pada karyawan PT. Kepsindo Indra Utama Padang.

Hasil penelitian ini mendukung pendapat Kirmeyer dan Dougherty dalam Iskandar dan Sembada (2012), Mustapha dan Ghee (2013), Altaf dan Mohamad Atif (2011), Mahendrawan, dkk (2015), menunjukkan bahwa beban kerja berpengaruh negatif terhadap kepuasan kerja karyawan. Hal ini dapat diartikan bahwa jika pegawai menganggap pekerjaan sebagai beban kerja yang berat seperti pekerjaan yang terlalu banyak, target kerja yang tinggi sementara watu penyelesaiannya terbatas menyebabkan karyawan merasa tertekan dan memicu munculnya rasa kelelahan serta berdampak terhadap penurunan kepuasan kerja karyawan.

\section{c. Pengaruh Kompensasi Terhadap Kinerja Karyawan PT. Kepsindo Indra Utama Padang}

Hasil uji hipotesis menunjukkan nilai koefisien regresi sebesar 0,664 dengan nilai signifikansi yaitu $0,000<0,05$. Dapat disimpulkan bahwa kompensasi berpengaruh positif dan signifikan terhadap kinerja karyawan PT. Kepsindo Indra Utama Padang. Temuan ini didukung oleh teori Hasibuan (2013) mengatakan apabila kompensasi yang diberikan kepada karyawan tepat maka kinerja karyawan akan meningkat sebaliknya kompensasi yang tidak tepat menyebabkan kinerja karyawan menurun. 
Kajian empiris yang turut mendukung temuan penelitian Hameed et al. (2014), Jamil dan Raja (2011) menyatakan bahwa kompensasi memiliki hubungan yang positif dan signifikan dengan kinerja karyawan. Tujuan dasar dari setiap perusahaan adalah untuk memberikan kompensasi karyawan dalam setiap cara yang memungkinkan. Kompensasi diperlukan untuk mendorong karyawan untuk bekerja lebih giat dengan harapan dapat meningkatkan imbalan yang diterimanya. Oleh karena itu kompensasi adalah entitas utama yang mempengaruhi kinerja karyawan.

\section{d. Pengaruh Kepuasan Terhadap Kinerja Karyawan PT. Kepsindo Indra Utama Padang}

Hasil uji hipotesis menunjukkan nilai koefisien regresi sebesar 0,190 dengan nilai signifikansi yaitu $0,026<0,05$. Dapat disimpulkan bahwa kepuasan kerja berpengaruh positif dan signifikan terhadap kinerja karyawan PT. Kepsindo Indra Utama Padang. Pengaruh positif menunjukkan bahwa kepuasan kerja karyawan yang tinggi akan mampu meningkatkan kinerja karyawan, sebaliknya kepuasan kerja yang rendah akan mengakibatkan menurunnya kinerja karyawan.

Hasil penelitian ini mendukung pendapat Robbins (2009:182-183) yang menyatakan bahwa hubungan kepuasan kerja dengan kinerja karyawan adalah pernyataan karyawan yang bahagia adalah karyawan yang bekerja dengan produktif. Jika diterapkan dalam suatu perusahaan maka dapat dikatakan perusahaan dengan karyawan yang terpuaskan cenderung lebih efektif, sehingga produktivitas semakin meningkat. Sejalan dengan penelitian dari Perera et al. (2014), Afshar dan Doosti (2016), dan Yang, et al (2014) menyatakan bahwa kepuasan kerja berpengaruh positif terhadap kinerja karyawan.

\section{e. Pengaruh Beban Kerja Terhadap Kinerja Karyawan PT. Kepsindo Indra Utama Padang}

Hasil uji hipotesis menunjukkan nilai koefisien regresi sebesar -0,146 dengan nilai signifikansi yaitu $0,034<0,05$. Dapat disimpulkan bahwa beban kerja berpengaruh negatif dan signifikan terhadap kinerja karyawan PT. Kepsindo Indra Utama Padang. Dapat disimpulkan bahwa karyawan PT. Kepsindo Indra Utama Padang menyikapi beban kerja sebagai suatu hal yang negatif dan dapat menurunkan kinerja karyawan.

Hasil penelitian ini menegaskan bahwa ketidaksesuaian jumlah pekerja dengan beban kerja yang dimiliki mengakibatkan pekerjaan yang diberikan menjadi tidak berkualitas, selain itu beban kerja yang berlebih menyebabkan kelelahan kerja pada karyawan dan memiliki dampak terhadap penurunan kinerja karyawan. Penelitian ini turut didukung oleh temuan penelitian Hastutiningsih (2018) menyatakan bahwa beban kerja berpengaruh negatif terhadap kinerja karyawan, hal ini menunjukkan kondisi dimana terjadinya peningkatan beban kerja akan diikuti dengan penurunan kinerja karyawan. 


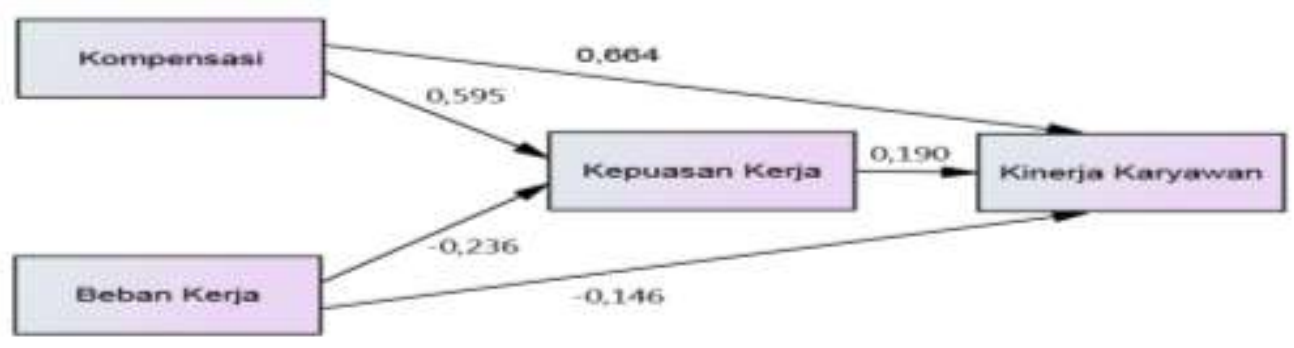

Gambar 1. Hasil Diagram Jalur

\section{PENUTUP}

Kesimpulan dari penelitian ini adalah variabel kompensasi berpengaruh positif dan signifikan terhadap kepuasan kerja karyawan PT. Kepsindo Indra Utama Padang, dengan demikian hipotesis tidak terbukti. Variabel kompensasi berpengaruh positif dan signifikan terhadap kinerja karyawan PT. Kepsindo Indra Utama Padang, dengan demikian hipotesis terbukti. Variabel beban kerja berpengaruh negatif dan signifikan terhadap kepuasan kerja karyawan PT. Kepsindo Indra Utama Padang, dengan demikian hipotesis terbukti. Variabel beban kerja berpengaruh negatif dan signifikan terhadap kinerja karyawan PT. Kepsindo Indra Utama Padang, dengan demikian hipotesis terbukti. Variabel kepuasan kerja berpengaruh positif dan signifikan terhadap kinerja karyawan PT. Kepsindo Indra Utama Padang, dengan demikian hipotesis terbukti. Nilai $\mathrm{R}$ square kedua persamaan sebesar 0,411, artinya variabel kinerja karyawan dijelaskan oleh kompensasi, beban kerja dan kepuasan kerja sebesar $41,1 \%$ dan sisanya sebesar 58,9\% dijelaskan faktor lain di luar model penelitian.

Hasil analisis jalur menunjukkan bahwa berdasarkan hasil analisis pengaruh langsung (direct effect) dan pengaruh tidak langsung (indirect effect) menunjukkan bahwa jalur langsung (direct effect) kompensasi berpengaruh paling kuat terhadap kinerja karyawan yang ditunjukkan dengan memiliki koefisien regresi pengaruh paling tinggi (dominan) sebesar 0,664. Hal tersebut lebih besar dibandingkan jalur yang lain. Maka dalam analisis jalur ini, kompensasi mestinya perlu mendapatkan perhatian dalam rangka meningkatkan kinerja karyawan yang cepat dan tepat.

\section{DAFTAR PUSTAKA}

Adeoye, A.O. dan Fields, Z. 2014. Compensation Management and Employee Job Satisfaction: A Case of Nigeria. Journal Social Science, Vol. 41, No. 3, pp. 345-352.

Afshar, H. S. dan Doosti, M. 2016. Investigating the Impact of Job Satisfaction/ Dissatisfactionon Iranian English Teachers' Job Performance. Iranian Journal of Language Teaching Research, Vol. 4, No. 1, pp. 97-115.

Altaf, A., dan Awam, M. I. 2011. Moderating Affect of Workplacee Spirituality on the Relationship Job Overload and Job Satisfaction. Journal of Business Ethics, 104(1), pp:93-94. 
Calvin., Ojeleye, Y. 2017. The Impact Of Remuneration On Employees' Performance (A Study Of Abdul Gusau Polytechnic, Talata-Mafara And State College Of Education Maru, Zamfara State). Arabian Journal of Business and Management Review, Vol. 4, No. 2, 2017.

Gupta, Manisha. 2014. Employees' Satisfaction Towards Monetary Compensation Practices. Global Journal of Finance and Management, Vol. 6, No. 8, pp. 757-764.

Hameed, A., Ramzan, M., Zubair, H.M.K., Ali, G. dan Arslan, M. 2014. Impact of Compensation on Employee Performance (Empirical Evidence from Banking Sector of Pakistan). International Journal of Business and Social Science, Vol. 5, No. 2, pp. 302-309.

Hasibuan, Malayu S. P 2012. Manajemen Sumber Daya Manusia Cetakan Keenam Belas. Jakarta : PT. Bumi Aksara.

Hastutiningsih, Artha, T. 2018. Pengaruh Beban Kerja Dan Lingkungan Kerja Terhadap Kinerja Karyawan Dimediasi Stres Kerja (Studi Pada PT. MSV Pictures Yogyakarta). Tesis (Online). Universitas Islam Indonesia Yogyakarta.

Iskandar, Sentot., dan Sembada, Gredi G. 2012. Pengaruh Beban Kerja, Motivasi Dan Kepuasan Kerja Terhadap Kinerja Pegawai Bank BJB Cabang Padalarang. STIE Pasundan Bandung, Jurnal Ekonomi, Bisnis \& Entrepreneurship Vol. 6, No. 1, April 2012, 26-38, ISSN 2443-0633.

Jamil, Bilal dan Naintara, Sarfaraz, R. 2011. Impact of Compensation, Performance Evaluation and Promotion Practices on Government Employees Performance VS Private Employees Performance. Interdisciplinary Journal of Contemporary Research in. Business, Vol. 3, No. 8, December 2011, 907-913.

Kopmans, L; Bernaard, C.M; Hildebrandt, Vincent.H; Vet, H.C.W; De, Beek, A.J. Construct Validity of the Individual Work Performance Questionnaire. Journal of Occupational and Environmental Medicine: 2014, 56(3), 331 337.

Kurniawan, Dwi, M. A., Hamid, Djamhur., dan Utami, Hamidah, N. 2014. Pengaruh Kompensasi terhadap Kepuasan Kerja dan Kinerja Karyawan Studi Pada PT. Prudential Life Assurance. Jurnal Administrasi Bisnis, Vol. 16 No. 1 November 2014.

Mahendrawan, I G., \& Indrawati, A. D. 2015. Pengaruh Beban Kerja dan Kompensasi Terhadap Kepuasan Kerja PT Panca Dewata Denpasar, E Jurnal Manajemen Unud, IV (11), ISSN:2302-8912, Hal 3936-3961.

Mathis, Robert L. dan John H. Jackson. 2011. Manajemen Sumber Daya Manusia, Edisi Pertama. Jakarta: Salemba Empat. 
Muguongo, M.M., Muguna A.T., dan Muriithi D.K. 2015. Effects of Compensation on Job Satisfaction Among Secondary School Teachers in Maara Sub-County of Tharaka Nithi County, Kenya., Vol. 3, No. 6, pp. 4759.

Mustapha, Noraani dan Ghee, W. Y. 2013. Examiningi Faculty Workloadias Antencedent of Job Satisfaction among Academic Staff of Higher Public Education on Kelantan, Malaysia. Journal Business and Management Horizons, 1(1), pp: 10-16.

Perera, G. D. N., Khatibi, A., \& Navaratna, N. 2014. Job Satisfaction And Job Performance Among Factory Employees In Apparel Sector. Asian Journal Of Management Science \& Education, Vol. 3.

Pontoh, Farham M. 2014. Pengaruh Kompensasi Dan Beban Kerja Terhadap Kepuasan Kerja Dan Dampaknya Pada Kinerja Pegawai Pada Badan Perencanaan Pembangunan Daerah Propinsi Sulawesi Tengah. e-Jurnal Katalogis, Volume 2 Nomor 1, Januari 2014 hlm 101-113. ISSN: 23022019.

Rivai, Veithzal. 2013. Manajemen Sumber Daya Manusia untuk Perusahaan: dari Teori ke Praktik. Jakarta: Raja Grafindo Persada.

Robbins, Stephen P, Timothy A. Judge 2009. Perilaku Organisasi. Jakarta: PT. Salemba Empat.

Siagian. 2013. Manajemen Sumber daya Manusia. Jakarta. Bumi Aksara.

Subekhi. A dan Jauhar, M.. 2012. Pengantar Manajemen Sumber. Daya Manusia (MSDM). Jakarta : Prestasi Pustaka.

Sugiyono. 2013. Metodelogi Penelitian Kuantitatif, Kualitatif dan $R \& D$. Bandung: Alfabeta.

Sunyoto, Danang. 2013. Sumber Daya Manusia. Yogyakarta: CAPS.

Tarwaka. 2014. Ergonomi Industri: Dasar-Dasar Pengetahuan Ergonomi dan Aplikasi di Tempat Kerja. Surakarta: Harapan Press.

Tjiabrata, Fernando R., Lumanaw, Bode., Lucky O.H. Dotulong. 2017. Pengaruh Beban Kerja Dan Lingkungan Kerja Terhadap Kinerja Karyawan PT. Sabar Ganda Manado. Universitas Sam Ratulangi. Jurnal EMBA, Vol.5 No.2 Juni 2017, Hal. 1570-1580.

Triyono, 2012. Paradigma Baru Manajemen Sumber Daya Manusia. Jakarta: PT. Suka Buku. 
Yang, Feng-Hua, et. All. 2014. Examining The Mechanisme Linking Behavioral Integrity and Affective Commitment; The Mediating Role of Charismatic Leadership. International Journal of Organizational Innovation (Online), Vol.6, No.3.pp:153-173.

Zaki, Hammam., dan Marzolina. 2016. Pengaruh Beban Kerja dan Kompensasi terhadap Turnover Intention melalui Kepuasan Kerja Pada Karyawan PT. Adira Quantum Multifinance Cabang Pekanbaru. Jurnal Tepak Manajemen Bisnis, Vol. VIII. No. 3 Sep 2016. 